\title{
Freedom, Autonomy, and the Cultural Study of Law
}

\section{Paul W. Kahn*}

In the spring of 1999, I published a little book with a big title: The Cultural Study of Law, Reconstructing Legal Scholarship. The ambition of the book was to clear a space within law schools for a study of law that was not directed at the issue of legal reform. I urged a theoretical approach free of the insistent question: "What should the law be?" The reasons for my plea were not new. The rule of law, I argued, is not just a set of rules to be applied to an otherwise independent social order. Rather, law is, in part, constitutive of the self-understanding of individuals and communities. In particular, Americans often identify themselves as citizens within a polity characterized by the rule of law. This is not the only way in which Americans imagine themselves, but it is a powerful way for many people.

To achieve such a disciplinary stance with respect to law's rule is particularly difficult, I argued, because the study of law is itself a part of the practice of law. An openness to reform is characteristic of the legal order, and a significant source of reform is the study of legal rules and institutions that occurs within the law school. Thus, an effort to shift the disciplinary attitude confronts not merely resistance arising from the personal ambition of those in a professional school to "have an impact" on legal practice, but a deeper problem of the co-optation of reason by the very object of study: the rule of law. Law professors, for the most part, are not studying law, they are doing law. Even to see this, however, requires a kind of Cartesian division of the self, such that the law professor's ordinary beliefs and professional practices become the object of his or her inquiry.

Anyone reading my book would quickly see that the title is grander than the actual project. For the most part, I have explored the links between constitutional law and the constitutive character of law. The culture of law's rule upon which I have focused is that which we acknowledge when we look to the Supreme Court as the literal embodiment of the belief that

* Robert W. Winner Professor of Law and the Humanities, Yale Law School. 
ours is "a government of laws, and not of men." Because constitutional law rests its claim to legitimacy on the realization of self-government, it provides a particularly compelling point of entry for an inquiry into the ways in which law both reflects and constructs the self. ${ }^{2}$

Much of the cultural studies of law movement has been an effort to shift the location at which we study law from the opinions of the appellate courts to the expressions of ordinary people carrying out the tasks of everyday life. Because of my focus on the constitutional rule of law, my work moves in the opposite direction. There is an unfortunate, but understandable, tendency to think that I am resurrecting a conception of culture as "high culture"- that which ordinary people lack - and that my focus on legal elites rests on a normative assumption about the superior value of the judicial opinion as compared to the representations of law that appear in popular culture. For these reasons, my work has been received with some unease by those whom I thought might be my natural allies. ${ }^{3}$

This skepticism has forced me to think further about the normative implications of my inquiry. In this Essay, I first locate my work in the field of cultural studies. My work is in some respects narrower and in others broader than that of others working in the field: narrower, in its focus on the rule of law as an expression of self-government; broader in its use of a distinctly philosophical methodology. In the final part of the Essay, I take up the issue of the normative implications of the differences in approach. At issue is not so much a difference over the character of law, but rather different conceptions of the relationship of the scholar to his or her project. Two different conceptions of freedom, and of the relationship of scholarship to freedom, lie behind this difference.

\section{WHERE We AgreE, OR HOW We Got TO WHERE We ARE}

Traditionally, the autonomy of the discipline of legal study was located within the doctrinal rules, which were thought to be capable of generating solutions to every actual controversy. The expert-a position claimed by both the judge and the law professor-could remain wholly within the domain of law in order to resolve social conflicts. To reach outside was to commit either the sin of "result-oriented" jurisprudence or that of

1. Marbury v. Madison, 5 U.S. (1 Cranch) 137, 163 (1803).

2. There is no reason to think that the self of constitutional self-government is a unified, single self that appears everywhere the same both here and abroad. Of course, from within constitutional law a hierarchical claim is made-all domestic law is regulated by, and ultimately a product of the Constitution. That internal claim, however, does not tell us whether the diverse forms of law as they work in the many domains of experience are in fact experienced as subordinate parts of a single order. The more compelling issue today is not the unity of the domestic legal order, but the relationship of the constitutional to the international nule of law. See Paul Kahn, Speaking Law to Power: Popular Sovereignty, Human Rights and the New International Order, 1 CHI. J. INT'L. L. 1 (2000). Cf. Richard Posner, Cultural Studies and the Law, 19 RARITAN, Fall 1999, at 42.

3. See Austin Sarat, Redirecting Legal Scholarship in Law Schools, 12 YALE J.L. \& HuMAN. 129 (2000). 
"usurping the legislative role." Legal practice and legal study formed a seamless whole. The judge and the professor knew the same things: one wrote opinions, the other treatises-or, more likely, law review articles. The law review article could become a favored style of presentation because of background assumptions that were just those embodied in the treatise-for example, that every area of law has a systematic completeness already known to the experts. Accordingly, the law review article could make a discrete intervention aimed at reforming a small part of the law, while assuming the relevant domain otherwise to remain stable. Law reviews were like pocket-parts-indeed, the new information technology has made law review articles accessible just as if they were pocket parts.

Legal scholarship had no other ambition than to systemize the knowledge claims implicit in the opinions. ${ }^{4}$ The world of the judge, of the professor, and of the elite legal practitioner was one world, staffed by the same individuals who would transit among all of these positions over the course of a career. This ambition is seen today in someone like Lawrence Tribe, who undertakes to write a treatise on constitutional law in order to systemize - to make into a single coherent whole-judicial doctrine. Having made a claim to this knowledge, he can now assume either of the other roles of practitioner or judge. This same vision is represented by Dworkin's mythic figure of Hercules, who personifies the perfect academic become the perfect judge. There is no longer any space between the different roles. Both aim to state what the law is by stating what they believe the law should be. The reform of law does not arise from knowledge claims external to law, but is the internal expression of the law itself. $^{s}$

This world of traditional, doctrinal legal scholarship was thought to have been largely broken apart by the rise of legal realism in the first half of the twentieth century. From the perspective of intellectual history, legal realism represented the transformation of legal scholarship by the rise of the new empirical social sciences. For the first time, the judge and his product - the judicial opinion - became an object of study by those who were not themselves a part of the extended practice of law. Attacking the knowledge claims of the doctrinalists - both judges and academics - the legal realists defeated the claims for the autonomy of law by showing that doctrine alone could neither determine nor explain outcomes. An

4. See, e.g., ThOMAs COOlEy, A TREATISE ON THE CONSTITUTIONAL LIMITATIONS Which Rest UPON THE LEgISLATIVE POWER OF THE STATES OF THE AMERICAN UNION (1868); WILLIAM PROSSER, HANDBOOK OF THE LAW OF TORTS (1941); JOHN WIGMORE, A TREATISE ON THE ANGLO-AMERICAN SyStem OF EVIDENCE IN TRIals of LaW (1923); SAMUEl Williston, A TrEatise on the LaW of CONTRACT (1920-22). See generally A.W. Brian Simpson, The Rise and Fall of the Legal Treatise: Legal Principles and the Forms of Legal Literature, 48 U. CHI. L. REV. 632 (1981).

5. See Roberto Mangabeira Unger, What Should Legal ANALYSiS BECOME? 36-40 (1996) (discussing rationalizing legal analysis). 
understanding of law had to work with a different vocabulary and a different set of explanatory rules from those deployed by the practitioners themselves. Here, the modern paradigm - and direct descendent of legal realism-is the law and economics movement. Law and economics, however, is only a particularly successful example of a set of epistemic assumptions embodied equally in a variety of disciplinary approaches, each of which sees law as epiphenomenal and seeks to reveal the "underlying" truth by deploying the tools and concepts of some other discipline.

Yet the capacity of the practice of law's rule to co-opt the scholars' claims to knowledge proved to be much stronger than the legal realists had imagined possible. Within a very short time, professors who alleged a loyalty to legal realism were themselves occupying the bench. Legal realism was no longer outside of legal practice looking in, but a dominant form of reason operating within the rule of law itself. The Brandeis brief anticipated this intersection in which the arguments made to the court drew from the insights and methodologies of the new social sciences. ${ }^{6}$ Thus, the rise of the social sciences not only transformed the structure of government institutions - for example, with the rise of the administrative agency-but also transformed the nature of legal reasoning. The postrealist language of constitutional law is the language of measurable interests, balancing, and deference to the claims of agency expertise. ${ }^{7}$ Instead of describing the competition of interests as what is "really" going on "behind" the legal rhetoric-the Holmesian critique of the pre-New Deal Court-interest balancing becomes the language of the Court itself and, accordingly, the material for doctrinal systematization. Not only was constitutional law transformed by the rise of new forms of knowledge, but a whole new domain of public law, characterized by its incorporation of bureaucratic rationality, arose to compete with constitutional discourse: administrative law.

This regular movement from critic to participant is a product of an epistemic self-reflection characteristic of law's rule. The rule of law is not just a set of rules like those one finds in a game that one can choose not to play. Rather, law appears as a legitimate source of authority; it could not do so if it appeared irrational or ignorant. Judges cannot speak for too long of a flat earth after everyone else in the society understands the earth to be round. The appearance of reason is not a sufficient condition of legitimacy, but it is a necessary condition - at least for a modern society.

The rule of law may be our tradition, but it is a tradition rooted in substantial part in Enlightenment beliefs about the place of reason in

6. See Brief for the Defendant in error, Mueller v. Oregon, 208 U.S. 412 (1908). See generally Ellie Margolis, Beyond Brandeis: Exploring the Uses of Non-legal Materials in Appellate Briefs, 34 U.S.F. L. REV. 197 (2000).

7. See T. Alexander Aleinikoff, Consthtutional Law in the Age of Balancing, 96 YALE L.J. 913 (1987). 
structuring a political association. If the legal order is committed to reason, and reason is understood to produce an ever-increasing growth of knowledge, then the order of law must hold itself open to knowledgebased reform. Sometimes that reform is dramatic and widespread. This was true of the rapid reform of law in the wake of the rise of legal realism. ${ }^{8}$

The character of knowledge claims within the legal order is a function of this need for legitimacy. Without purporting to set forth a necessary, formal logic of the legal order, we can still describe the general character of the epistemic conditions that a modern legal order must purport to satisfy. First, the law has to be objective: There must be a truth of the matter. If there were not an object external to the legal decision-maker, then there could be no assurance in advance that the experts would agree on a single answer to legal questions. Without this kind of objectivity, the claim to expert knowledge of the law would not be capable of solving any controversy. ${ }^{9}$ Second, the law has to be neutral. If the product of legal inquiry depends on the character of the inquirer-or even worse, on the character of the parties making legal claims - then claims of expert knowledge would not merit deference from the parties to a controversy. Without neutrality, the autonomy of law would only be a statement about the interests of those who exercise power to decide under the law. Law would be no more stable than the flow of political power. Finally, law must be a system in the sense of a reasonably ordered whole. One has to be able to move from one proposition to another within the legal order by means of established procedures and justified inferences. There must be a reasonably supported chain of argument from common starting points to a common resolution. This requirement is analogous to that of "repeatability" with respect to scientific experiments. Without this transparency to reasons, law's legitimacy in a democratic order would again be in doubt. ${ }^{10}$

For the classic doctrinalist, the autonomy of law rested on the claim that the expert knowledge of law satisfied all three of these demands for objectivity, neutrality, and coherence. The claims of the doctrinal science of law, however, were thoroughly discredited by the legal realists, who left the law professor looking like a snake oil salesman who had illegitimately worked his way into the university. Legal decisions and legal rules, the legal realists taught us, have to be understood in a

8. The continuity of the legal order across time is at stake in the conception of reform. Because he emphasizes revolution over reform, Ackerman must locate the continuity of the legal order in the unity of the acting subject: the People. See BRUCE ACKERMAN, 1 WE THE PEOPLE: Foundations (1991).

9. See Owen Fiss, On Objectivity and Interpretation, 34 STAN. L. REV. 739 (1982) (questioning how much epistemic certainty is required to satisfy a demand for objectivity).

10. See Robert Post, Theories of Constitutional Interpretation, in LAW AND THE ORDER OF CULTURE 27 (1991) (arguing that authority of law "embodies the values of stability, predictability, and reliance which are necessary to the legitimacy of any modern legal system"). 
social/political context that is not captured by the categories and descriptions of law. Law satisfies none of the normative criteria of autonomy: it is not objective, neutral or coherent.

Despite the victory of legal realism, the power of these epistemic norms remained. If they serve a legitimating function, they cannot easily be discarded. Nevertheless, they had to find a new footing apart from the traditional science of law. Precisely as a result of the success of the legal realists at simultaneously colonizing the academy and the bench, this battle today is waged on two fronts at once-within the judiciary and within the university. Most famously, it is the framework within which many of our most pressing constitutional disputes are fought out. Here, the battle pits those who claim to be strict constructionists against those who are inappropriately labeled "non-interpretivists." But it is also fought on a daily basis in the law schools, which have experienced a constant methodological crisis for a generation as scholars search for and critique the epistemic grounds for legal reform. Behind the explosion of studies of "law and ..." lies this legitimation crisis.

The strict constructionists claim that judges must restrict themselves to a narrow reading of the Constitution, although even here there is disagreement on whether a narrow reading sticks only to the text or also appeals to original intent (and whose intent matters). The point of this narrowness is to satisfy just those demands for objectivity, neutrality, and coherence described above. The fear is that a non-interpretivist approach provides the judge a space for free play of his or her own values, allowing legal decision-making to become another forum for political and moral disagreement. Thus, the dispute over law's autonomy becomes a battle over the legitimacy of judicial decision-making. The reach of judicial decisions should not exceed the domain within which these norms of objectivity, neutrality, and coherence can extend. Beyond that domain, not knowledge but consent is the sole source of legitimate authority in a democracy. With consent, we move from legal to political institutions.

The non-interpretivists react defensively, claiming first that the resources of text and history cannot satisfy the epistemic demands that could ground the autonomy of law. Just as the legal realists delegitimized the claims of the doctrinalists early in this century, modern theorists use the same strategies to delegitimize the knowledge claims of the strict constructionists. Texts, they argue, are multivalent, and history is a wideopen field for interpretive disagreement. ${ }^{11}$ Even to begin a legal inquiry requires decisions resolving complex questions of interpretation with respect to the level of generality at which questions are posed and answers articulated. Does one ask what the Framers said in 1789, or what they

11. See, e.g., JACK RAKOVE, ORIGINAL MEANINGS: POLITICS AND IDEAS IN THE MAKING OF THE CONSTITUTION 3-22 (1996); Paul Brest, The Misconceived Quest for the Original Understanding, 60 B.U. L. REV. 234 (1980); Lawrence Lessig, Fidelity in Translation, 71 TEX. L. REV. 711165 (1963). 
would have said 200 years later, or something in-between, such as what is the current meaning of what they said then? There is no end to these questions, and no agreement on the answers. Modern disputes over statutory interpretation reflect the transference of these same interpretive controversies from the problem of reading the Constitution to that of reading statutes. ${ }^{12}$

These are extremely bitter battles on the bench because the underlying issue is the legitimacy of the judicial claim to say what the law is. The dispute is framed as a question of whether one is engaging in law at all. Thus, on the abortion issue, Justice Scalia accuses the majority of abandoning "reasoned judgment [for] personal predilection," and declares such an "unprincipled" approach is "more than one should have to bear."13 Justice Stevens returns the accusation in the recent federalism cases, accusing the states-rights majority of a "judicial activism [that] represents such a radical departure from the proper role of this Court that it should be opposed whenever the opportunity arises."14

Despite the dissenters' resistance to stare decisis, the strong role of precedent within legal reasoning inevitably creates a movement toward judicial self-regulation. However illegitimate a decision may appear to those who disagree with it at first, it nevertheless operates as a precedent. Roe v. Wade ${ }^{15}$ is normalized by Casey, just as Seminole Tribe v. Florida ${ }^{16}$ has been normalized by the numerous Eleventh Amendment cases in recent years. Within the law schools, however, there is no corresponding regulatory mechanism. One consequence of this has been a growing division within the academy among the diverse approaches to law and legal argument. Not bound to each other by a need to decide anythingapart from the occasional faculty appointment-disciplinary proliferation continues, with each discourse having less and less contact with its competitors. ${ }^{17}$

The modern law school lives with this burden of establishing the form of knowledge appropriate to law. Here, the non-interpretivists must confront the fact that they cannot simply dismiss the implicit norms behind claims for the autonomy of legal knowledge, since those norms ground the legitimacy of legal decision-making. The non-interpretivist must meet those standards of reason or provide an alternative legitimating ground. Modern constitutional theory, starting with Alexander Bickel's identification of the countermajoritarian difficulty, ${ }^{18}$ is just such an

12. See, e.g., RONALD DWORKIN, LAW'S EMPIRE 313-54 (1985); WILLIAM ESKRIDGE, DYNAMIC STATUTORY INTERPRETATION (1994).

13. Planned Parenthood v. Casey, 505 U.S. 833, 984-85 (1992) (Scalia, J., dissenting).

14. Kimel v. Florida Bd. of Regents, 528 U.S. 62, 65-66 (2000) (Stevens, J., dissenting).

15. Roe v. Wade, 410 U.S. 113 (1973).

16. Seminole Tribe v. Florida, 517 U.S. 44 (1996).

17. This same phenomenon appears in the increasing proliferation of specialized law journals.

18. Alexander Bickel, The Least Dangerous Branch: The Supreme Court at the Bar 
attempt. In substantial part, this amounts to an effort to ground the incorporation of the legal realists' interest-balancing approach into constitutional law. ${ }^{19}$

The law school operates as a kind of funnel through which other disciplines are fed into the law itself. This is one half of the legal realists' legacy of turning to the resources of social science-resources outside of the discipline of law-and insisting that the law be informed by an intellectual expertise that meets contemporary epistemic standards. Thus, the critique of law as epiphenomenal continues as a theme common to scholars on both the left and the right. It runs from the variety of forms of Marxism and feminism, on one side of the political spectrum, to conservative charges that liberal judges have implemented a political program unsupported by legitimate legal sources, on the other. All want to get to the "truth" of the matter; all believe that having reached that truth, legal reforms should follow.

The other half of the legal realists' legacy is the movement of the boundaries of legal discourse such that what had been outside comes to have a place within the law itself. To speak of the autonomy of law in the law school today is to describe a domain capable of expanding to include virtually any kind of knowledge claim. Economics, for example, is not just an external perspective that can be applied to law. It also claims a place within the legal academy as yet another source of what the law is. The same is true of moral theory, as illustrated by the work of someone like Ronald Dworkin. ${ }^{20}$ Institutionally, there is a characteristic movement of knowledge claims from the periphery to the center of the law school, and from there into the patterns of judicial reasoning. The outsider regularly becomes the insider through the powerful need of law to claim the support of reason.

From this vantage point, we can see the similarities and differences of critical legal studies (CLS) and the law and economics movements, the two major claimants to the legal realist tradition. Both share the negative, critical theme of piercing the language of law and deploying in its place an expert language better able to grasp the truth upon which law rests. They bring different resources to a shared perception that interests and the material capacities to realize these interests are foundational considerations. They differ, of course, in their understandings of the origins of interests and the way in which interests are realized. Nevertheless, they share a positive belief that the reform of law must

OF POLITICS (1962).

19. Compare LEARNed HAND, THE BILL OF RightS (1958) (objecting that the Court was becoming a legislative body) with BICKEL, supra note 18, (embracing an educational and representational role for the Court); see also Paul Kahn, The Court, the Community and the Judicial Balance: The Jurisprudence of Justice Powell, 97 YALE L.J. 1 (1987).

20. See generally RONALD DWORKIN, FREEDOM \& LAW: 76 MORAL READINGS OF THE AMERICAN CONSTITUTION 1-38 (1996). 
follow from the realization of the truth each purports to recognize. Both believe that the practice of law should be informed by the truth revealed through legal study. One pursues reform under the norm of efficiency and the other under that of justice, but for each this is simply the affirmative side of the critical exposure of the epiphenomenal character of law. ${ }^{21}$

That law and economics has been far more successful in its critical and reformist ambitions than CLS reflects the same constellation of forces seen in the dominant place of economics in social science departments and in the formulation of policy. Again, we should not expect the truth operating in law to look very different-at least in the medium termfrom that operating in the broader society. It is not surprising, therefore, to find some of the leaders of the CLS movement today pursuing a reformist enterprise that, in its focus on economic institutions, looks surprisingly like some aspects of the law and economics movement. ${ }^{22}$

Those who pursue the cultural study of law often want to escape this entire matrix of thought in which the study of law becomes a contest over the legitimacy of knowledge claims and over the direction of legal reform. Like the CLS scholars, they too tend to think that legal claims are less a form of knowledge than a form of power-more precisely, that the truth of legal propositions rests not in some objective fact or principle accessible to rational inquiry, but in the relationships of power that such claims sustain. These scholars are no less interested in recovering that which law's knowledge removes from sight. Recovery, however, no longer means discarding the language or practices of law as simply epiphenomenal. The power at issue substantially creates and sustains itself through the claims of law. Accordingly, there is a need to investigate the ways in which law is constitutive of group and individual identities and values.

If truth and power are bound together, there is no way to abandon one for the other, or to view either from the perspective of the other. Neither provides a solid ground upon which to stand without the other. The old opposition between claims for the autonomy of law, on the one hand, and for the epiphenomenal character of law, on the other, dissolves. Without a clear division between inside and outside, the critique of the autonomy of law no longer leads to the same process of cooptation by which the external becomes internal.

Cultural studies tend to see law as nothing in the abstract; rather, law is a set of sites of social conflict, and a set of resources-institutional and

21. Early participants in CLS focused on destabilizing_-"trashing"-claims of legal knowledge and resisted the reformist ambition. See, e.g., Mark Kelman, Trashing, 36 STAN. L. REV. 293 (1984). Over time, critical legal scholars too had to answer the question "what should the law be?" Answering the question is a condition of participation in the practice of law.

22. See, e.g., Roberto Mangabeira Unger, Democracy Realized: The Progressive ALTERNATIVE (1998). Duncan Kennedy lists among his current research interests "left wing law and economics," see <http://www.law.harvard.edu/faculty/directory/>. 
rhetorical-for those involved in these conflicts. Sites and resources, however, do not exist independently of the claims and conflicts. Individuals do not first have interests which they then take to the law. Individuals literally find themselves in these sites deploying these resources; we are always already there.

Scholars of law and culture focus on the materiality of law, the way in which law simultaneously embodies the interests of particular groups and shapes those interests-and even shapes the identities of those who understand themselves as members of such groups. Law must, on this view, be studied in ways that are historically specific and deeply contextualized. The turn to historical context reveals a dynamic process in which power is contested for the sake of ideas, values, and interests. The contest is often fought within, and over, the terms of legal claims for recognition of identity as well as of particular interests.

To understand law, accordingly, we have to investigate how it works in its multiple uses. Use is not simply in the Supreme Court, but just as much in the divorce court; not simply by the judges, but by the parties. To know what the law means to people, we should ask them. Do not ask the Chief Justice. Instead, ask the ordinary person who comes into contact with the law at multiple sites in his or her daily life: ask those who must negotiate a divorce or pay a traffic ticket. Knowledge of the law begins with good survey data. The study of legal culture has its roots not only in the CLS concern for power, but equally in the law and society concern for the empirical investigation of the social. ${ }^{23}$ This turn to the social, away from the opinions of the legal elite, means that the study of the culture of law tends to slide toward law's representation in "popular culture." The concept of legal culture seems to require both forms of approach to the ordinary: statistical representation and analysis of the symbolic productions of everyday life.

Some who study the culture of law suspect that I may be on the wrong side of all of these divides. My inquiries tend to focus on the top of the legal hierarchy - on the judges and professors, rather than on ordinary citizens in their confrontations with, and deployments of, law. There is indeed implicit in my work a claim about the autonomy of law's rule. Moreover, many who study the culture of law approach the subject from the perspective of group interests - for example, minorities or womenthat might provide a ground for resistance to, and thus for evaluation of, legal understandings. Since I do not take such a perspective, I face the threat that the subject will be swallowed up by law. Thus, I need to save the subject from law's imperial claims. ${ }^{24}$ These are the points I want to address. While doing so, I do not mean to discredit the work of others. The issue here is not who has the correct approach or who can properly claim

23. See Jonathan Simon, Law After Society, 24 LAW \& SoC. INQUIRY 143 (1999).

24. See Jack Balkin, Ideology as Constraint, 43 STAN. L. REV. 1133, 1137 (1991). 
the label "cultural study." There can be multiple forms of inquiry into the nature of law, even multiple forms of a cultural study of law's rule.

Moreover, we are in broad agreement on many of the underlying premises of the significance of the turn to culture. We share a similar frustration with the terms of legal inquiry as it has continued to cycle through the debate first realized in the opposition between the doctrinalists and the realists. We agree that law plays a constitutive role for individuals and communities, and that interpretation and power go hand in hand. None of us believe that law is an objective or neutral set of propositions, yet we share an interest in the way in which claims of objectivity and neutrality operate within the law. We also agree that the culture of law needs to be understood in its relationship to other cultural products, and that there is no law in the abstract. There is only a field of social relationships organized, in part, through assertions of law. We accept the hermeneutic turn, and for that reason are interested in exploring the contributions that the study of rhetoric and interpretation can make to understanding the culture of law. Our interdisciplinary interests are strong and reach as much toward the humanities as the social sciences. We agree on the need for historical inquiry into the forms and patterns of legal understandings. Like other cultural products, law has a history that sets the limits of possibility at any given time. To understand why we order the legal world as we do, we need to understand where these patterns came from and how they changed over time. An interest in history does not commit one to any particular form of historical explanation or any propositions about historical causation. Nevertheless, a concern with the genealogy of legal understandings is common to many of those who study the culture of law, including myself.

\section{WHERE WE DISAGREE}

More than anything else, we disagree on the sites at which a cultural analysis can be usefully applied. I have been particularly interested in using a cultural studies approach to understand the character of the legal imagination of those who consider themselves, and are considered by others, to be the spokespersons for the rule of law: law professors, judges and justices. What is the structure of the legal imagination of those who are most deeply committed in their professional and personal lives to the rule of law? They engage in a constant process of reification and objectification of the categories of legal analysis: for example, the sovereign people, the judicial role, legislative intent, the permanent Constitution, and precedent. How do they imagine the world when they invoke such concepts? How does that world give meaning to their sense of their own identity and their understanding of the political community? How did this way of thinking come to seem so "natural?"

Of course, this inquiry would be of less interest if it failed to make 
contact with the beliefs maintained by a more substantial portion of the population. Studying the Justices is not the legal equivalent of studying the string theorists in the physics department. There are deep resonances between what the judges and professors say, on the one hand, and some very basic beliefs central to a broadly available American culture of the rule of law, on the other. We find the elements of this set of beliefs in much of our public rhetoric, regularly deployed for over 200 years.

This set of beliefs is often referred to as our "national faith" or our "civic religion." Its standard terms are endlessly repeated in civics classes and on every occasion when someone-even if only a private citizenmust explain the legitimacy of a claim put forth for public acknowledgment and response. These terms are so basic that anyone who rejects them is seen as radical, dangerous, or, more likely, unstable. Just as they are repeated in the endless invocations of the rule of law in public discourse, they are repeated in the dominant forms of modern political theorizing, beginning with Hobbes's linkage of the concepts of sovereignty, social contract, and political science. The rule of law in this tradition is a product of a sovereign people constituting itself through an act of constitutional construction founded on the insights of political science. ${ }^{25}$

Much about the set of beliefs that constitute law's rule is obvious. It is only obvious, however, because it is so deeply enmeshed in our political culture. That this is our culture, and not some universal order of law, becomes clear as soon as one compares it to the discourse and beliefs of other states and peoples-even other liberal democracies. Our immediate and easy recourse to the language of law is hardly universal. The export of our legal rules often fails to produce anything that looks to us like a polity under the rule of law. We often speak loosely about the need for certain habits of law-abidingness, when we try to explain the failure of a government of law to work elsewhere. Habits are forms of practice that seem to come "naturally" because the world is imagined to have a character within which these forms of behavior make sense. This perception of the world is hardly natural. I have sought to explain the how and why of our perception of legitimacy under law.

Thomas Paine announced that in America "law is king." There has since been an unbroken, public commitment to the idea that we live under the rule of law, not men. Paine's proposition works as both a descriptive and a normative claim. Thus, the deepest criticism that one can make of political behavior is that it is in violation of a legal norm. Who in this country does not believe that "not even the President is above the law"? ${ }^{26}$ And who

25. See James TUlly, Strange Multiplicity: CONSTItUtionalism IN AN AGE of Diversity 62-70 (1995) (discussing the seven features of modern constitutionalism).

26. See generally Nixon v. Fitzgerald, 457 U.S. 731, 766-67 (1982) (White, J., dissenting); Clinton v. Jones, 520 US. 681, 697 n. 24 (1997) (discussing American rejection of the absolute immunity that is an attribute of the British monarchy). 
does not understand the deep resonance of the assertion, in the face of injustice, that the injured party is going to take the case "all the way to the Supreme Court"? Of course, we all know that the President can get away with much, and that the Supreme Court is not in the business of doing justice. But even as we acknowledge the failures of these propositions as descriptive claims, we nevertheless feel those failures as points of illegitimacy in our political arrangements. Law should be king. Of this, we are quite certain.

One saw, for example, fascinating permutations on this theme in the recent impeachment process, in which both sides tried to claim for themselves the virtue of law and to cast the other as "mere politicians"those who in bad faith would use the form of law to advance factional ends. The supporters of impeachment appealed to this norm of universal and equal application of the rule of law; opponents claimed that President Clinton was being singled out for prosecution on the basis of an alleged violation of law that would not be pursued against any other individual. The battle for public legitimacy was not fought over what happened-nor over who could claim popular support - but over which side could claim the virtues of law's rule. ${ }^{27}$ Each sought to label the opposing arguments a "perversion" of law for merely political purposes. Of course, an even deeper indication of our public commitment to law's rule is the fact that removal of the President takes the form of a legal proceeding: Our Constitution provides no room for a no-confidence vote based on a loss of political support. Here, as elsewhere, we find a deep inclination toward juridifying what might otherwise be seen as political disputes. ${ }^{28}$

The Supreme Court regularly appeals to an understanding of its own role as the guardian of law's rule in American political life, and the Court remains our most respected governmental institution. The Court started its career of judicial review by making three fundamental claims: Ours is a government of law, not men; it is the Court's role to say what the law is; and the law is the expression of the opinion of the people. ${ }^{29}$ When the Court speaks the law, it speaks in the name of the sovereign people. This was the vision of Marbury, and it remains the central normative claim of the Court, appealed to, for example, in Casey when the Court felt compelled to reassert the grounds of its own legitimacy in the face of the abortion controversy:

Like the character of an individual, the legitimacy of the Court must be earned over time. So, indeed, must be the character of a Nation of

27. See Charles Collier \& Christopher Slobogin, Terms of Endearment and Articles of Impeachment, 51 FLA. L. REV. 614 (1999).

28. Rereading these lines at the end of November, 2000, I note the repetition of this cycle of claims and counter-claims in the post-election Florida controversy. See Paul Kahn, The Call to Law is a Call to a Faith in Higher Politics, L.A. TIMES, Nov. 24, 2000, at B7.

29. See PaUl KaHN, THE REIGN of LaW: Marbury v. Madison and the Construction of AMERICA, (1997). 
people who aspire to live according to the rule of law. Their belief in themselves as such a people is not readily separable from their understanding of the Court invested with the authority to decide their constitutional cases and speak before all others for their constitutional ideals. If the Court's legitimacy should be undermined, then, so would the country be in its very ability to see itself through its constitutional ideals. ${ }^{30}$

That this understanding is shared by other politicians-as well as the electorate-is suggested by the fact that it has become virtually inconceivable for a politician, including the President, to oppose a court order. For example, the widespread resistance to desegregation, following Brown v. Board of Education, ${ }^{31}$ is not viewed as a story of democratic resistance to an unelected judiciary. Rather, that history is read as a story of the progressive triumph of law over a demagogic politics of special interests. Defiance of the Supreme Court by public officials appears to us as the equivalent of military defiance of civilian command. Indeed, these are linked aspects of belief in the rule of law: to defend the nation is to defend the Constitution. The object of the oath of office required of representatives and governmental officers is to "support this Constitution."

The ambition of the cultural study is not just to delineate the substantive character of these beliefs of the Court and its audience, but to understand how it all works. How has the Court created an appearance of itself as the voice of the people? What is it that we see, and fail to see, when we look to the Court?

This language of law's rule is our dominant, although not exclusive, language of legitimacy. We are, of course, quite capable of speaking the language of majority rule and electoral politics. But even that language rarely works against the rule of law. When it does-for example, Jefferson's resistance to Marshall, Lincoln's to Taney, and Roosevelt's confrontation with the Lochner Court-it is a strong indication of a national crisis. Moreover, the resolution of such crises usually includes a claim to recovery of the larger narrative of law's rule. The crisis is contained, localized, and resolved by the identification of a specific error which is then excised from the legal corpus: consider Dred Scott $v$. Sanford, ${ }^{32}$ Plessy v. Ferguson, ${ }^{33}$ and Lochner v. New York. ${ }^{34}$

The narrative offered in support of the legitimacy of every political act or actor moves to the plane of constitutional order surprisingly quickly. When challenged, a governmental action will be justified by reference to some particular regulation or decision, which will be supported by some

30. Planned Parenthood v. Casey, 505 U.S. 833, 868 (1992).

31. 347 U.S. 463 (1954).

32. 60 U.S. 393 (1856).

33. 163 U.S. 537 (1896).

34. 198 U.S. 45 (1905). 
statutory authority, which will find its source in the Constitution. Because we assume these levels of support, judicial review is easily sought and widely expected as the test of legitimacy. There is no point at which politics is visibly unleashed from law. ${ }^{35}$ Political opposition to judicial rulings will, for this reason, inevitably be framed as an opposing legal claim. In this instance, it will be said, the Court misinterpreted the truth of the Constitution.

The recent dispute over the appropriate course of action with respect to the six-year-old Cuban boy, Elián Gonzales, is a good example of the role of the legitimating discourse of law's rule. The Clinton Administration immediately took the position that his disposition was a matter to be determined by law, not by the politics of our relationship with Cuba, nor by politics in the streets of Miami. When "application" of the legal rule led to a decision to send him back to his father, there were massive demonstrations by the Cuban-American community. But when asked about the grounds for this demonstration, the leadership's response was not framed in terms of the political power of this community, nor in terms of their political opposition to Castro. Rather, a counter-claim of law's rule was put forth: The protestors accused the Administration of sacrificing a claim of legal right to a political goal of rapprochement with Castro. They wanted to make sure that the child had "his day in court." Law, it seems, can only be opposed by law, even in the middle of spontaneous forms of political action. ${ }^{36}$

Of course, law does not eliminate politics in any dispute. But what is striking is the need for all sides to frame their actions in terms of law's rule. We do not capture what is going on by approaching the legal contest as if it were merely a rhetorical cover for the political disputes. Not only does the invocation of law have institutional consequences, but it is offered as a normative justification that can settle disputes on terms common to all sides. To win the contest at law really is to win the controversy. ${ }^{37}$

These are the sort of disputes in which I have been interested: contests

35. Even the political question doctrine represents only a judicial pronouncement that the Constitution has vested a substantial discretion in the political branches. See Louis Henkin, Is There a Political Question Doctrine?, 85 YALE L. J. 597 (1976).

36. See Rick Bragg, Judge Upholds Plan for Return of Boy to Cuba, N.Y. TIMES, Mar. 22, 2000, at Al (quoting Luis Felipe Rojas, Press Secretary for Movimiento Democracia, saying that the "demonstrations had been organized to demand that Elián's case be heard by the courts.") As the Elián crisis continued, a claim upon Elián surfaced from an entirely different dimension-a claim that he had deep religious significance, having been saved by God. This is a reminder that law and political action do not exhaust the dimensions of experience. The assertion of the miraculous may be more powerful than law for those who have faith, but it is not a claim toward which those who believe in our civic religion are likely to be sympathetic.

37. This is why overruling precedents is such a difficult subject both in the deliberative processes of the Justices, see, e.g., Planned Parenthood v. Casey, 505 U.S. 833, 869 (1992) (O'Connor, Kennedy, and Souter JJ), and as a matter of theory, see, e.g., Kevin Stack, The Practice of Dissent in the Supreme Court, 105 YALE L.J. 2235 (1996). 
that go to the issue of the legitimacy of the entire structure of governmental authority. This is the point at which issues of legitimacy become issues of citizen identity. The language of law's rule appeals to our understanding of who we are as citizens. Much of my work has tried to offer a kind of phenomenology of this distinctive American political culture of the rule of law. ${ }^{38}$

This is a key point of difference between my work and that of many others in the field of cultural studies of law. I have not been writing about the culture of law per se, here or anywhere else, but about the American culture of political legitimacy through law's rule. My concern has not been with the operation of the multiple bodies of law-e.g., tort, contract, family - but with the nature of the understanding of a constitutional order of law that appears to citizens to make legitimate claims upon them. Other domains of law are not entirely beyond my vision, but I approach them from the perspective of the constitutional construction of self and nation.

Our discourse of law's rule is not primarily a discourse of rights - a point about which both liberal theorists and their communitarian critics are often mistaken. Rather, the American discourse of legitimation through law's rule is a discourse of popular sovereignty. We only get to the discourse of rights when we ask what it is that the popular sovereign "says." Combining the who and the what of this speech gives us the deeply felt, but weakly conceptualized, relationship of will and reason at the foundation of our concept of political legitimacy. ${ }^{39}$ This relative priority of popular sovereignty over rights is not a universal characteristic of legal discourse. It points to a uniquely American culture of law's rule.

My point has never been to praise or to condemn this set of beliefs in law's rule. I have not urged it on people or expressed regret that it may be a cultural form of ultimate meanings that is dying for many. I have no doubt that many people do not experience popular sovereignty and law's rule as something affecting their own lives, let alone defining their own identity. Some, because they have a less political understanding of what is important in their lives; some, because they understand themselves to be oriented toward an emerging global order that has displaced their identification with the nation-state; and some, because they understand themselves through an identification with a group that sees itself as victimized by the majority's actions and beliefs, which they perceive to be embodied in the law. Yet I suspect that many of these people can still understand the pull of the culture of law's rule; they still feel something of the effects of this set of beliefs. They are likely still to think that what needs to be done is to fulfill the promise of the rule of law, i.e., the

38. See PaUl KaHN, LEgITIMACY AND HISTORY: SELF-GOVERNMENT IN AMERICAN CONSTITUTIONAL THEORY (1992); KAHN, supra note 29.

39. See Paul Kahn, Reason and Will in the Origins of American Constitutionalism, 98 YALE L.J. 449 (1989). 
promise of the Constitution. They may fight for group recognition and an expansion of rights, but they are hard pressed to find a language outside of our rhetoric of law's rule, and a set of institutions outside our legal practices, within which to frame their political struggles.

I have sought to understand where this cultural form of law's rule comes from, how it holds together, and what meaning of self and community is maintained by those who operate with this set of beliefs. Avoiding advocacy of law's rule, I have, nevertheless, tried to maintain a respectful attitude toward the culture of law; not because it is better than other cultural forms or somehow represents a higher truth, but because it has provided a matrix of meanings for generations of Americans. Kant argues that what deserves our respect is the individual's capacity to formulate a moral rule. Accordingly, respect is due to that in which every individual is the same. But respect is also due to the capacity for difference: for who we are, as well as for an ideal we all might be. Respect is due not only to the universal, but formal, capacity of every individual to appeal to reason; it is due also to the substantive capacity to create and maintain a culture. We cannot respect that capacity without respecting its products, any more than we can respect the artist but not her art.

Respect hardly means that one should ignore the injustices, repressions, and inequalities sustained in the name of the rule of law, or of any other cultural form, whether religious, political, or familial. None of the forms of our cultural inheritance are free of guilt in this respect. The barbarism done in the name of beliefs - of what we call high as well as low culturedoes not lurk very far below the surface of most of our ideals. ${ }^{40}$

Central to my inquiry has been an investigation of the way in which popular sovereignty appears to those who participate in the culture of law's rule. This inquiry into the appearance of popular sovereignty, in turn, has raised a host of questions about the imaginative shape of time, space, representation, and authority within the rule of law, as well as about the nature of legal texts, the authorial voice, and interpretation. These are only the general topics under which I have organized the inquiry, not an exhaustive list of categories. In one form or another, all of these inquiries are directed at the subject's imagination of the self as a citizen under law's rule. To borrow a phrase from Charles Taylor, I have explored the "sources of the self" at work in the American conception of the citizen under law's rule.

I have tended to focus on the strongest claim that we imagine possible within the political order: that is, the claim for self-sacrifice made upon the citizen. For many Americans, the rule of law has been a deadly serious affair, providing an ultimate meaning and meriting an ultimate sacrifice.

40. See Walter BENJAMIN, Theses on the Philosophy of History, in ILlumnations 253, 256 (Hannah Arendt ed. \& Harry Zohn trans., 1969) ("There is no document of civilization which is not at the same time a document of barbarism."). 
The rule of law is a kind of short-hand way of referring to a matrix of beliefs and practices within which the citizen acknowledges the possibility that the state will make a demand upon his or her life and, regardless of personal interests, the legitimacy of that claim will have to be acknowledged. ${ }^{41}$

If we try to imagine a state that could never make such a claim upon the individual, we are either imagining an "illegitimate" state or we are imagining a political order very different from that which we have experienced within the modem nation-state. ${ }^{42}$ Indeed, imagining the compelling quality of this claim is a way to begin to distinguish the symbolic form of political life from the symbolic form of our moral life. Politics and morality do not always intersect, as becomes obvious when we examine the political justice of warfare in which morally innocent combatants are thought to be appropriate targets of deadly force. ${ }^{43}$ Conversely, the demand for an international law of human rights rests on an intuition that the moral and political orders must have some minimum contact.

I have sought to describe the substance of those beliefs that amount to a kind of faith in the popular sovereign, which is simultaneously the source and meaning of the rule of law. This inquiry takes no position on the validity of the truth claims put forward under the rule of law. Nor does it imply anything about the normative justifications that could be offered for such beliefs. Understanding the shape and the origins of the constellation of beliefs in the rule of law is a very different enterprise from the philosophical inquiry into the conditions under which a government can make legitimate claims upon individuals. The latter is a project in political justification, an aspect of normative political theory. ${ }^{44}$

I have often used an analogy to the study of religion in order to explain my own work. As with the study of religion, I have argued that we must suspend belief in the truth of law's rule, if we are to investigate the imaginative shape of the culture of law's rule. Just as a cultural study of religion focuses on religious experience rather than on the truth of religious doctrine, a cultural study of law should focus on the character of

41. Jefferson, in his First Inaugural Address, spoke of this: "I believe this . . the strongest Government on Earth. I believe it the only one where every man, at the call of law, would fly to the standard of the law, and would meet invasions of the public order as his own personal concern." Thomas Jefferson, FIRST INAUGURAL ADDRESS, repinted in 1 DOCUMENTS OF AMERICAN HISTORY 187 (Henry Commajer ed., 1973).

42. Consider in this regard, the struggle of the European Union states to unify foreign and defense policies, and whether the European Union itself would properly be regarded as a state were it to achieve this unity.

43. See Paul Kahn, Nuclear Weapons and the Rule of Law, 31 N.Y.U. J. INT'L. L. \& PoL. 349 (1999).

44. In Legitimacy and History, KaHN, supra note 38, I take up the issue of legitimacy of constitutional authority. I conclude that the search for legitimacy is necessary but ultimately impossible to resolve, because the question of legitimacy takes constitutional thought beyond the capacities of constitutional institutions. 
experience under belief in the rule of law.

We should not ask, for example, whether law's rule is really founded in the popular sovereign, but rather how it is that the popular sovereign appears in and through the categories of the legal imagination. Like the Judeo-Christian God, the popular sovereign is the reified subject of a process of interpretation. Both the divine and secular sovereigns are imagined as the point of origin of a text. Apart from moments of miraculous appearance through revelation or revolution, access to both sovereigns is achieved only through reading and interpreting texts. Similarly, we should not ask whether the rule of law maintains the neutrality and objectivity it claims, but rather how the belief in law's neutrality and objectivity operates in the citizen's understanding of his or her relationship to legal claims. Again, the analogy is to the equal position of all souls before God, regardless of worldly distinctions of wealth, power or honor. We want to know how the denial of distinction works in religious belief, not whether that radical equality states an "objective truth."

The analogy to religion helps to sharpen the point of difference between myself and others pursuing the cultural study of law. Many of the latter assume that the way to pursue a cultural study of religion is to begin by investigating the beliefs of parishioners. I, on the other hand, would begin with an investigation of the theologians. These inquiries are not mutually exclusive. If we want to understand Christianity, it would be wrong to think that we can ignore Augustine, Aquinas or Luther. But it would be equally wrong to think that the beliefs of the parishioner are irrelevant or that they fail to make contact with those of the theologians.

The theological analogy goes to one of the basic points of misunderstanding. Essentially, my critics have the genealogy of my work wrong. The point of intersection between my work and their own may be Clifford Geertz. ${ }^{45}$ They often come out of a social science tradition for which empirical research-the gathering of data through the field studyis necessary to the scholarly enterprise. Geertz, for them, may represent a change in the understanding of the object of those field studies, but not in the essential character of the work. But the genealogy of my work is philosophical, not anthropological.

The cultural study of law's rule that I pursue figures in an enterprise that begins with Kant and the subjective turn to transcendental philosophy, moves through the historical objectification of reason in Hegel, and then expands into the study of diverse cultural forms with Ernst Cassirer ${ }^{46}$ and Suzanne Langer. ${ }^{47}$ This neo-Kantian approach takes a number of forms in

45. See Clifford Geertz, The INTERPRETAtion of Cultures (1973).

46. See 1-3 ERnSt CASSIRER, THE PHILOSOPHY OF SYMBOLIC FormS (Ralph Manheim trans., 1953-57).

47. See Suzanne Langer, Philosophy in a New Key (1951). 
the twentieth century, including Wittgenstein's Philosophical Investigations, ${ }^{48}$ Foucault's inquiries into truth and power, ${ }^{49}$ and Charles Taylor's work on the sources of the self. ${ }^{50}$ Foucault refers to "the historical a priori," 51 which is an accurate description of the kind of philosophical inquiry that I have pursued. Geertz is a critical figure linking these two genealogies, as he himself recognizes when he acknowledges the importance of Wittgenstein to his own investigations.

The most important influence on my work is neither Geertz nor Foucault, but rather Cassirer's inquires into the variety of symbolic forms. ${ }^{52}$ This is just the spirit with which I approach the study of the culture of law's rule, as a distinct symbolic form that constructs one possible world of meaning. That world exists alongside others constructed by deploying other symbolic forms. Thus, while I have tried to sketch a picture of law's rule as a complete world, that is, one that can make sense of all the phenomena that can appear within it, I have been careful to describe this as a world that is deeply contested by other symbolic forms. These other forms also participate in constructing the meaning of our political life; they too make claims to completeness which compete with those of the rule of law. This leads me to emphasize points of contestation different from those my critics emphasize. While they are interested in the contests within law, I am interested in the confrontations between legal and non-legal understandings of our experience. Again, these are not mutually exclusive inquiries.

In The Reign of Law, ${ }^{53}$ I described a kind of symbolic competition between the rule of law and what I termed "political action." The latter describes an order of politics characterized by contrast to law's rule. It is a world in which meaning is located in individuals performing unique acts; it is not a world of pre-existing rules to which individuals appeal in order to make sense of their experience. The ambition of political action is to create the new, rather than to preserve existing meanings. The political actor claims to represent the current people, while the legal subject understands the self to represent a transgenerational community. Political action takes revolution, not constitutional preservation, as its paradigmatic political act. The distinction can be thought of as one between the potential and the actual. Under the symbolic form of law's rule all possible meaning is present before the act occurs: The event only has meaning as the realization of a potential that was already there. This is what it means

\footnotetext{
48. See Ludwig Wittgenstein, Philosophical Investigations, 3RD ED. (G.E.M. Anscombe trans., 1999).

49. See Michael foucault, The Order of Things, at xxii (1990).

50. See Charles Taylor, Sources of the Self: The Making of the Modern IDENTITY (1992).

51. FOUCAULT, supra note 49 , at xi.

52. See CASSIRER, supra note 46.

53. KAHN, supra note 29.
} 
to recognize the act or event as an instance of a legal rule. Under the symbolic form of political action, the meaning of the event is established in its actual appearance as a unique product of contingent forces. Rules alone will produce no act; something must happen. Only then does the contest of meaning begin.

Our political life often appears as a competition between these different forms of perception and understanding. We honor both Revolution and Constitution. We experience the promise of the "New Frontier," the "New Deal" or a new "Contract with America": we yearn for a kind of individual political heroism. But we also experience the claim of faith in the constitutional order of law that we inherit from our predecessors. This is not a competition between events and actions, but between the forms of understanding within which we perceive their meanings. Consider, for example, an act of Congress. It can be understood as the realization of a constitutional rule establishing the possibility of a range of legislationthe issue before the Court when the constitutionality of the act is challenged. But it can equally be understood as a unique event, bringing policy innovations to a contemporary problem.

Although I describe these as two competing symbolic forms, that does not mean that they are somehow hermetically sealed off from each other, both in our actual experience and in the explanations and public justifications of events. We can appreciate the politically effective character of Chief Justice Warren's leadership of the Supreme Court-and of the Court itself at times-just as we can admire the political actor who defends a rule of law even when it is against his or her self-interest.

In Law and Love, ${ }^{54}$ I described a more elusive competitor with the symbolic form of law's rule: the world of love, in which law itself is identified with the fallen condition of mankind. Within this cultural form, the highest values realized in our mutual engagements are those of grace, forgiveness, and mercy. This Christian claim of a love beyond law is also an inescapable part of our imaginative construction of the domain of the political. We imagine the alternative to law's rule to be not just a state of nature in which life is short, nasty, and brutish - the natural world of the social contact theorists. Alongside of that image, we imagine a state of grace that is beyond, not below, law. Political meanings are perceived against this horizon of self-transcendence.

The rule of law appears as both a triumph over nature and a tragedy of our fallen condition. In the midst of the constitutional project, Madison writes that "if men were angels no government would be necessary." 55 This idea of law as tragedy remains a powerful belief at the heart of the symbolic form of love. ${ }^{56}$ This belief is continuous with the early colonial

54. PaUl KaHN, LaW AND Love: The TRIALS OF KING LeAR (2000).

55. The Federalist No. 51, at 322 (James Madison) (Clinton Rossiter ed., 1961).

56. It would be interesting to explore President Clinton's invocation of this symbolic form 
experience of religious exiles seeking to create utopian, Christian communities. American experience, I suspect, remains far more oriented toward religion than that of other Western nations.

Again, the point is not to offer a defense of law's rule, but to understand it as a structure of experience. That experience maintains itself against competing possibilities. We always speak of "the rule of law, not men." But the "rule of men, not law" has its own possibilities that we can value over the virtues of law. The competition with law's rule comes from both the experience of revolution as a form of political action, and of love as a form of religious experience.

Each of these symbolic forms is complete within itself; each offers an understanding of the entire world of possible experience. "Complete" here does not mean bounded or conceptually determined. It means only that there is no point at which the symbolic form-for example, the rule of law-confronts an act, event, or actor that is beyond its capacities of cognition. In the same way that there is nothing beyond the reach of an aesthetic, religious, or scientific understanding, there is nothing outside the possible domain of legal and political sensibilities. There is nothing to which law does not extend, nothing to which love does not extend, and nothing that cannot be understood as the beginning of the new rather than the continuation of the old. Most of us are quite good at organizing discrete areas of experience under different cultural forms: We do our religion in church and our aesthetics at the museum. ${ }^{57}$ But we also understand the unlimited potential of each form and the ever-present possibility of conflict among them. Aesthetic sensibilities can surface in the laboratory, and love can appear within the courtroom. Most obviously, law's rule can appear as a form of political contest, and political contest can appear as a form of the rule of law. We can find the meaning of a presidential contest, for example, in political action or in its realization of the constitutionally established rule for presidential succession.

In pursuing this claim for completeness of a symbolic form, some may suspect me of returning to the traditional claims for the autonomy of law. But this is a misunderstanding. Indeed, it is a senseless proposition within the structures of experience that I describe. The autonomy of law suggests a kind of objectivity, a form of reasoning in which law alone can-and should-determine outcomes of particular controversies. On my understanding of a symbolic form, however, no outcomes are determined by the form itself. Belief in the rule of law, deployment of legal categories and the legal imagination, is what unites all sides in a legal controversy. Whatever the outcome of a controversy, it will be formulated as the consequence of law's order. But so, then, would the opposite outcome. If,

following his confession of $\sin$ in the Lewinsky affair.

57. See generally, e.g., MiCHAEl WALzER, SPHEREs Of JuStice: A DEFENSE OF PluRALiSM AND EQUALITY (1983) (discussing the normative separation of distinct domains of experience). 
for example, $R o e^{58}$ had been reversed in Casey, ${ }^{59}$ that reversal would have been justified in an opinion celebrating the "recovery" of the rule of law. That recovery would have been no less true than the celebration of stare decisis we find there instead.

David Hume describes a kind of completeness of a symbolic form in his essay On Miracles.$^{60}$ His point there is that our commitment to a scientific understanding is such that nothing that happens-however miraculous it may appear-is beyond our commitment to this order of meaning. That which we do not understand, we describe as still an open question-an area for further scientific inquiry, not an appearance of the miraculous. There is no point at which the scientific form of explanation simply ends; no point beyond which we say all else is God's mystery. The same is true from the other side- that is, for those who hold deeply religious beliefs. For example, the problem of the evidence of evolution is, for them, not one that shakes the foundations of faith, but rather a puzzle to be solved within the terms of faith. The rule of law is equally a way of making sense of an entire world of experience. About every controversy, we are sure that there is a legal resolution. There is always an answer. We have this faith before we know what that outcome is; we maintain our faith even after we know the outcome is not what we might have hoped.

Neither the positions of the parties nor the outcomes of the cases can be determined by appeal to these shared understandings alone. To think that it could be otherwise would be like saying that disputes among different Protestant sects can be determined within the autonomy of the religious form. There would be a kind of confusion of levels of explanation here. Of course, each side to the dispute believes that law-or religion—supports their position; each will make their own truth claims. But bracketing belief in all such claims is exactly the first step of self-distancing that I described above as a necessary condition of the form of cultural study that I pursue.

Here, one model for my work has been that of Thomas Kuhn, on the history of science. ${ }^{61}$ Kuhn engaged in the same sort of neo-Kantian project as the others I mentioned earlier. ${ }^{62}$ In Legitimacy and History, ${ }^{63} \mathrm{I}$ took a specifically historical approach to the American belief in self-government under law, tracing the way in which this idea has undergone successive Kuhnian crises, each of which has caused a re-imagining of the basic form of the idea of constitutionalism. I do not deny that particular groups will use legal categories to advance their own interests. Just as Kuhn would not deny that the parties engaged in scientific disputes at any particular

58. Roe v. Wade, 410 U.S. 113 (1973).

59. Planned Parenthood v. Casey, 505 U.S. 833 (1992).

60. DAVID HUME, AN ESSAY ON MIRACLES (Holyoake 1856).

61. Thomas Kuhn, The Structure of SCIENTIFic Revolutions (1962).

62. See supra notes $46-50$.

63. KAHN, supra note 38 . 
moment will lay claim to all the truth that is available within the existing categories, so legal disputants will reach for all the truth available within the general understanding of law's rule. ${ }^{64}$ In neither science nor law are the results of these particular controversies irrelevant to the changing character of the symbolic form itself.

Although belief in the rule of law is quite independent of the outcome of particular controversies at any given moment, this does not mean that nothing could ever force us to forsake the belief. After all, for many people God did die sometime in the last 200 years. The same thing may be going on with respect to the nation-state-and the rule of law is a way of understanding the meaning of the nation-state. The globalization of legal rules through the development of international law may be a good thing, but it is a profound mistake to believe that the emerging culture of a global order of law is simply an enlargement of our traditional culture of law's rule. Most importantly, the new global order of law puts rights, not sovereignty, at its foundation. A cultural study of law's rule warns us not to take any comparisons for granted; it suggests that we will make little progress understanding what is at stake if we look only to the content of legal rules. ${ }^{65}$

In truth, religion has operated as more than an analogy in my work. Running throughout my work have been two claims not shared by many of those doing cultural studies of law. First, I have been struck by the way in which the American belief in law's rule is continuous with many large religious themes in the West. ${ }^{66}$ There has been a substantial migration of religious conceptions into legal thought. ${ }^{67}$ For example, in both the religious and the secular traditions, law is founded on the expression of sovereign will; in both, the rule of law maintains through ordinary time the meaning of the sovereign's revelatory act. The history of the nation for both is understood as the narrative of maintenance of a legal order suspended between these extraordinary moments in which the sovereign reveals itself. The rule of law constitutes one historical communityreligious or secular - even as generations, concerns, and material interests shift. ${ }^{68}$ I have traced this intertwining of our most basic religious narratives with our "secular" conception of ourselves as a people living

64. See Richard Fallon, A Constructivist Coherence Theory of Constitutional Interpretation, 100 HARV. L. REV. 1189 (1987).

65. See Kahn, supra note 2.

66. The Reign of Law, supra note 29 , explicitly links the internal structure of the symbolic form of law's rule to an Hebraic cultural inheritance; Law and Love, supra note 54, turns to the Christian inheritance.

67. See, e.g., CARL SCHMIT, Political Theology 32 (1916) ("All the pregnant ideas and institutions of modern political thought are in essence secularized forms of theological doctrines and institutions.").

68. The problem of the continuity of the authority of law across generational change is an important point of contact between analytic jurisprudence, see, e.g., H.L.A. HART, THE CONCEPT OF LAW (1961), and cultural studies of law. 
under a rule of law that we have given to ourselves.

Second, I have also suggested that it is not just the forms of the imagination that migrate from the religious to the political, but the locus of ultimate concern. An ultimate concern provides a life-defining good-one that can make a compelling claim upon the self. The issue is not whether such claims are justified, but rather whether they are acknowledged by the subject. The rule of law is a system of beliefs capable of calling forth individual sacrifice on a massive scale. This is the language within which generations of Americans have understood the legitimacy of the claim that the state may make upon their own lives. Much in my work has, accordingly, focused on the violence of law.

This concern for law's violence is shared by others in the field of cultural studies, but I have approached it a bit differently. Where others are often interested in the violence done in the name of law to individuals and groups, I am interested in violence as a form of sacrifice. ${ }^{69} \mathrm{I}$ explore the forms within which individuals understand the possibility of sacrifice as an expression of ultimate commitment. For example, I have written of the relationship between the rule of law and nuclear weapons, trying to understand the imagination of self that makes it possible to see mutual assured destruction as an affirmation of a community of equal citizens under law. ${ }^{70}$

The rule of law is a deadly serious business, calling forth our capacities for sacrifice. This seriousness differentiates this symbolic form from others-for example, art or science-and places it within a genealogy of ultimate concerns. In modern political cultures, nationalism has absorbed much of our faith in ultimate meanings. American nationalism has been linked to a particular understanding of the rule of law-one in which law is thought to be the imposition of a constitutional order upon the people, by the people themselves. Belief in the rule of law draws as much on myth as on reason, on faith as on evidence. I have studied these elements of our faith.

\section{WHAT IS AT STAKE?}

One characteristic of a cultural approach to law is that it positions itself on the line separating internal and external accounts of law. ${ }^{71}$ This capacity to participate within a cultural form for the purposes of description and interpretation, yet to suspend belief in its norms, has been critical to my endeavors in two ways: first, in defining the normative attitude of respect characteristic of a cultural study; second, in offering a

69. Robert Cover shared this interest. See Robert Cover, The Supreme Court, 1982 TermForeword: Nomos and Narrative, 97 HARV. L. REV. 4 (1983); Robert Cover, Violence and the Word, 95 YALE L.J. 160 (1986).

70. See KAHN, supra note 43.

71. See supra notes 1-24 and accompanying text. 
kind of transcendental proof of individual moral freedom. These two points are related, and in that relationship lies the only kind of normative implications that this cultural study can claim.

If it were not possible to bracket one's normative commitments in the course of the scholarly inquiry, we would have no way of ever escaping the very conceptual forms that we are endeavoring to understand. Without an Archimedean point upon which to stand either intellectually or morally, we would be able to say only that the forms of positive analysis are yet another deployment of the available symbolic tools within which we comprehend experience. There would be no point from which we could say that the reflective, analytic stance gives us a better understanding than the non-reflective stance. Re-categorization of ordinary experience in the name of truth is not necessarily a more accurate representation. Alchemy, astrology, or reading the signs of divine revelation in the ordinary experience of nature may all be examples of "false sciences." Some people make the same claims against Marxist, neoliberal or feminist forms of analysis - and, indeed, against the prevailing forms of legal analysis.

The only way out of the limitless claims of the hermeneutic circle is self-reflexive. That is, we must be able to take the categories of experience as a subject of reflection even as we deploy them. This does not guarantee their truth, as if we can establish a correspondence with an external reality. We can never get to the thing itself in this sense. It does mean, however, that there is no point of our experience against which we cannot construct a critical space from within which we can examine the structure of that experience. We try to reveal the sense of the subject's world from within, but we take up that task by simultaneously standing without. ${ }^{72}$

The concern with method, as I have pursued it, is a concern with setting forth the analytic conditions of such a critical approach, that is, with establishing the conditions under which this bracketing of normative belief and distancing from conceptual structure can occur. This is a kind of modern counterpart to the Cartesian effort to deploy radical doubt in order to reach a firm foundation from which to rebuild a system of knowledge. Instead, however, of establishing a well-founded order, the end now is simultaneously to grasp contingency and system-again the idea of an historical a priori. The methods of inquiry I have urged have been genealogical and architectural, which together represent this double aspect.

Legal concepts, particularly the large, framing concepts-sovereignty, constitutionalism, the judicial role, or even the rule of law itself- have their own histories. The point of the genealogical inquiry is not simply to show the historically contingent character of our beliefs, but to grasp the way in which these concepts continue to bear remnants of their past. This form of inquiry forces us to see the ways in which we remain bound to the

72. See S. Lukes, Moral Diversity and Relativism, 29 J. PHIL. EdUC. 173 (1995). 
long history of Western structures of belief about claims of ultimate authority, even as we may think of ourselves as citizens of a modern age of reason.

Today, freedom has become embedded in the realization of our own contingency. It is no longer found in the certainty of a moral rule or the fulfillment of desire; neither Kantianism nor utilitarianism offers a model of freedom adequate to modern understandings of the deep contingencies of belief and desire. The self has been irretrievably historicized. This means that the free subject must comprehend both the self and the whole course of history at the same moment. In our knowledge of the physical universe, we have reached just such an awareness. We grasp our own position in time, but we simultaneously see the whole, from the big bang to the final collapse of the sun. We have a god's-eye view of the whole, not as a matter of theological speculation, but of scientific knowledge. This awareness is too much for most of us, most of the time. Yet, we insist that the only possibility of free thought is to stand apart, and force ourselves to contemplate the whole. The same is true of that reduced scale of being that amounts to our position in political life.

Pressing the genealogical inquiry is a way of stepping out of one's own historical moment, that is, of suspending belief long enough to understand the contingency of contemporary beliefs. The order of law is not the product of abstract reason, nor is it the product of an objective reason working itself pure through some sort of evolutionary, historical process. At various moments, claims of both sorts have been put forward as the ground of the reasonableness of law's rule. These claims, however, are made from within the legal order; that is, they are expressions of selflegitimation within legal practice. I have called such internal, legitimating efforts "the auto-theory" of law; they too are objects for cultural study. Without the security of a myth of progress or a belief in the formal logic of law, we comprehend beginning and end, while remaining just where we are. In that comprehension, we realize the characteristic freedom of the contemporary period.

While the genealogical approach creates distance by emphasizing historical contingency, the architectural inquiry creates distance by holding up a standard of coherence. This form of inquiry assumes that the rule of law is an entire system of order, and that each of its elements rests on a network of meanings constitutive of the whole. Thus, we can start at any point-for example, any judicial opinion — and work through it to the whole.

The philosophical rigor of the idea of system again forces on us a kind of Cartesian abstraction from the self. We can always ask whether we can better express the system of related ideas upon which each part draws and to which it contributes. The point is not that there is a provable logic to the whole; nor is the point that there is a single position outside the cultural form that gives us a kind of comprehensive view of the whole. The 
external position is an attitude or an ambition.

A symbolic form is not a formal, logical order; it does not even follow the principle of non-contradiction. The resources of legal reasoning are predominantly analogical. They are quite capable of reaching mutually exclusive answers to a single question. Legal controversy is resolved, in the end, by an assertion of authority, not by agreement on a single interpretation. $^{73}$

An appropriate analogy is to the interpretation of a novel, in which we can ask how each aspect makes sense in light of all the others, and how the whole appears from the perspective of each aspect. Even to begin such an interpretive inquiry, we have to be able to imagine a position outside the whole. If we were wholly outside, however, the novel would be a closed book. Conversely, if we were wholly within, we would be limited to the terms and sequence of positions within the plot. We cannot pursue this relationship of part to whole without positioning ourselves simultaneously inside and outside the world created by the novel. The same is true with a cultural form: we are of it and beyond it.

Together, the two approaches make us observers of our historical moment and critics of our own beliefs. Yet it remains our moment and they are our beliefs. We do not find an absolute point of justice or the good; nor do we find the pure voice of the popular sovereign speaking the law. Nevertheless, this critical distance is enough to establish the transcendental conditions that support a claim for moral freedom. Precisely because we can construct this distance from our ordinary ways of knowing and responding, we always stand apart from context. This critical space represents the possibility of surprise. We imagine that we can act differently, that we can come to a new insight about the world or ourselves. We imagine and are entitled to imagine that the future is open and that it is open to us. We do not know where the inquiry will lead us theoretically or practically.

The freedom that is the condition of this inquiry is both negative and positive. Negative, because one must withdraw from one's commitments, at least temporarily. But positive as well, because the very act of interrogating one's beliefs implies the existence of some measure beyond those beliefs. No cultural form is immune from the inquiry that begins with the Socratic elenchus: Are the practices and beliefs supported by that form justified upon examination? Thus, we have some idea of a substantive norm that founds the free inquiry. The negative space of critical inquiry does not overwhelm us, leaving us with nothing to say and nowhere to go. We do not fall into an abyss of silence. Rather, the negative freedom of inquiry establishes a discourse in which we inevitably feel that we are approaching an ultimate good. We know there is an end-

73. See Paul Kahn, Interpretation and Authority in State Constitutionalism, 106 HARV. L. REV. 1147 (1993). 
a telos-to our discourse, even as we acknowledge that we may never reach that end.

The capacity to ask the Socratic question is an affirmation of a freedom necessary to the human condition: We are never so bound by culture, historical circumstance, or social practices and beliefs that we cannot establish a critical distance from our ordinary selves. We cannot help but believe that we are free agents precisely because of this capacity for normative and intellectual bracketing. Nor can we help but believe that this capacity exists in others. This belief is the foundation of a recognition of the possibility of a free discourse with every other subject. The openness of both participants in such a discourse to surprise at the outcome of this mutual engagement expresses this experience of freedom. ${ }^{74}$ Knowing what we do of ourselves, and of how we have come to be ourselves, we cannot help but believe that we might be moved by others. Historicized and historicizing, we become aware of our own contingency. Recognizing that contingency, we are free to recognize others as equal participants in a common discursive endeavor.

Just at this point, the cultural study of law's rule-or any other symbolic form-crosses from positive to normative. It is another version of the oldest form of proof of the good that we have, for it states the conditions of belief in the Platonic forms. It is what Kant called a transcendental proof and what Charles Taylor has referred to as the "best account" of our moral experience. ${ }^{75}$ It is that form of an account without which we cannot make sense of the experience of ourselves as simultaneously a part of, and apart from, the world within which we find ourselves. We cannot help but acknowledge the possibility of free inquiry and freedom of the will, even if we do not always put a positive value on that possibility.

Liberal political philosophers believe that we can construct a political order out of this experience of a kind of transcendental freedom. The "original position" is a metaphor for this capacity to bracket all of one's commitments, to divide the self and become the critical observer. I, on the other hand, take the Socratic view that the experience of this freedom is an end toward which we always have to work from within a cultural practice. This critical capacity is a transcendental condition of inquiry; it serves as a kind of regulative idea. It is not a substantive position that we can obtain or from which we can build a political order.

The freedom at issue here is moral, not political. It exists only as a possibility within a critical inquiry. That inquiry will take a discursive form whether or not the interlocutor is the self or an other. The discursive experience of freedom can never be institutionalized in a political form because it can give no ground to any authoritative voice or hierarchical

74. See Hans Gadamer, TRUTH AND Method 379 (J. Weinsheimer \& D. Marshall trans., Crossroad 2d ed. 1989) (discussing the "fusion of horizons").

75. TAYLOR, supra note 50 , at 58. 
position. It always unsettles our commitments. In this respect, a neoKantian study of symbolic forms produces a kind of super-liberalism beyond even that imagined by Roberto Unger. ${ }^{76}$ Where I see an ultimate incommensurability between the political and the moral, his superliberalism remains a political project. ${ }^{77}$

Not just liberal philosophers, but all who take the reform of law as the limit of their ambition remain bound to a political conception of freedom. Even the best of legal orders is an inadequate field for this experience of a radical freedom. We cannot escape the burden of trying to reform the law, but we should not mistake that end for a complete account of freedom. Critical inquiry is a philosophical practice that is commensurate with the idea of a free self that is never exhausted within the conditions of experience.

In sum, the normative implications of the cultural study of law, as I have described it, have nothing to do with the affirmation of "high culture" against popular culture, or an affirmation of the legal achievements of the dominant interests of the society against the legal experiences of ordinary citizens. The normative implications arise out of the necessary understanding of freedom that lies at the foundation of the possibility of such an inquiry. The different forms of cultural inquiry reflect, therefore, not only different intellectual genealogies - philosophy and social science - but different conceptions of the free character of the subject.

In the end, my critics would bring their inquiry into line with the great reformist ambition of the law: to build a political order commensurate with their vision of truth. It is not an accident, for example, that Sarat and Kearns's book, Law in the Domains of Culture, ends with an essay on the Components of Cultural Justice. ${ }^{78}$ There is an inevitable movement from the cultural study of law's power to marginalize, suppress, and exclude to an embrace of the reformist ambitions of liberation politics and the politics of identity. I do not disapprove of that end, but it is not the end at which I aim. In the capacity for critical distance, I find a free self that is always beyond the reach of any symbolic form to exhaust. Beyond politics and law, even beyond language, is a self and an ultimate good that we necessarily affirm each time we take up the Socratic inquiry.

In these competing conceptions of freedom lies the deepest ground for my effort to focus the cultural study of law on the discourse of the bench and the academy. A commitment to anti-elitism threatens to relieve the inquirer of too much responsibility. Some argue that no one but a small

76. ROBERTo MANGABEIRA UNGER, THE CRITICAL LEGAL STUDIES MOVEMENT 41 (1986).

77. See Paul Kahn, Democracy and Philosophy, in Deliberative Democracy and Human RIGHTS 247 (Hongju Koh \& Ronald C. Slye eds., 1999).

78. Andrew Ross, Components of Cultural Justice, in LAW IN THE DOMAINS OF CULTURE 203 (Austin Sarat \& Thomas R. Kearns eds., 1998). 
elite reads Supreme Court opinions or law review articles; no one hears the self-justifying rhetoric of our high public officials. We must, they claim, look to the popular representations of law's order. Yet when we look there, we may not find ourselves. For law professors are participants in the debate among the politically powerful.

We are seriously in and of the law, while television, movies, and popular literature are forms of entertainment that may not engage our deepest beliefs. While we may occasionally find ourselves in local courts, the Supreme Court occupies our own image of the legitimate rule of law. One can too easily end up studying the beliefs of others, which means there is nothing at risk for the self. There is nothing wrong with such an inquiry as a discipline of study. But if the cultural study of law is to be a project of transcendental freedom, rather than another angle on the project of legal reform, then the beliefs exposed must be our own, and the distance created must be within ourselves.

Bringing cultural study into the heartland of the legal academy is a way of putting the self at risk. Here, I agree with the critical legal studies movement. In the end, I fear they were too often captured by the law professor's ambition for reform, but they did see that the study of law can be a practice of freedom. For me, this is central to the genealogy of my approach which extends back through Kant to Plato and the origins of western philosophy. The subject of that inquiry is always the self. Without putting the self at risk, there can be no experience of freedom. Philosophy, even in the form of a cultural study of law, need not justify itself at the bar of politics.

At stake, then, in this competition between social scientists and philosophers over the meaning of the cultural study of law, is a larger vision of the nature of freedom and the possibility that even an inquiry into the rule of law can be more than an intellectual inquiry and more than a plan for reform; it can be a practice of freedom. Philosophy must be a high-risk enterprise, or else it becomes only a continuation of politics under another name. 
HeinOnline -- 13 Yale J.L. \& Human. 1722001 


\section{Deploying Law and Legal Ideas in Culture and Society}


HeinOnline -- 13 Yale J.L. \& Human. 1742001 